American Journal of Applied Sciences 8 (10): 984-988, 2011

ISSN 1546-9239

(C) 2011 Science Publications

\title{
Production and Characterization of Bio-Char from the Pyrolysis of Empty Fruit Bunches
}

\author{
Mohamad Azri Sukiran, Loh Soh Kheang, Nasrin Abu Bakar and Choo Yuen May \\ Engineering and Processing Division, Malaysian Palm Oil Board, No. 6, \\ Persiaran Institusi, Bandar Baru Bangi, 43000 Kajang, Selangor, Malaysia
}

\begin{abstract}
Problem statement: The palm oil industry generates an abundance of oil palm biomass such as the Empty Fruit Bunch (EFB), shell, frond, trunk and Palm Oil Mill Effluent (POME). For 88 million tones of Fresh Fruit Bunch (FFB) processed in 2008, the amount of oil palm biomass was more than 26 million tones. Studies about production of bio-char from oil palm biomass are still lacking in Malaysia. So, this study was aimed to: (i) determine the effect of pyrolysis temperatures on bio-char yield (ii) characterize the bio-char obtained under different pyrolysed temperatures. Approach: In this study, pyrolysis of EFB was conducted using a fluidized fixed bed reactor. The effect of pyrolysis temperatures on bio-char yield was investigated. The pyrolysis temperature used ranged from 300$700^{\circ} \mathrm{C}$. The elemental analysis, calorific value, surface area and total pore volume of the bio-char were determined. Results: The highest bio char yield of $41.56 \%$ was obtained at an optimum pyrolysis temperature of $300^{\circ} \mathrm{C}$ with particle size of $91-106 \mu \mathrm{m}$ and the heating rate of $30^{\circ} \mathrm{C} \mathrm{min}{ }^{-1}$. The calorific values of bio-char ranged from 23-26 $\mathrm{MJ} \mathrm{kg}^{-1}$. Conclusion: It was found that the bio-char products can be characterized as carbon rich, high calorific value and potential solid biofuels.
\end{abstract}

Key words: Empty Fruit Bunches (EFB), pyrolysis, bio-char and palm oil

\section{INTRODUCTION}

Biomass is an important renewable source contributing to the world's economy, sustainability and energy security. In developing countries, the use of biomass is of high interest as these countries have economy largely based on agriculture and forestry. The use of biomass as raw material for bioenergy depends on the state of the art of the technologies which are safe and economical to transform biomass into manageable value-added products (Sensoz et al., 2006).

The palm oil industry generates an abundance of oil palm biomass such as mesocarp fiber, shell, Empty Fruit Bunch (EFB), frond, trunk and Palm Oil Mill Effluent (POME). While much research has been carried out to utilize oil palm biomass for value-added products, its commercial utilization is not widespread. Most of the oil palm biomass is returned to the field as mulch to retain land fertility. As fossil fuel is depleting, there is an urgent need to exploit any type of biomass as renewable sources by converting them to various transportable forms of green fuels. Technologies to transform biomass into bioenergy vary from normal combustion to thermal processes requiring higher temperature and pressure such as pyrolysis and gasification.

Pyrolysis is a thermal decomposition process that occurs at moderate temperatures in which the biomass is rapidly heated in the absence of oxygen or air to produce a mixture of condensable liquids (bio-oil), gases and bio-char. It is one of the most recent renewable energy processes and promises high yields of liquid with a minimum of gas and bio-char if it is carefully controlled. The yields and compositions of end products of pyrolysis are highly dependent on types of biomass, chemical and structural compositions of biomass and other physical parameters such as temperature, heating rates, reactors, particles size, coreactant and others. To achieve an advanced process for improving product yields from pyrolysis of selected biomass, in-depth investigations on the mechanism of biomass pyrolysis are needed.

Bio-char are black solid. The bio-char is intermediate solid residue, which is formed in the pyrolysis of most biomass. At low temperature and low heating rate process, high bio-char production can be gained from the process. The bio-char is believed to contribute to the formation of Polycyclic Aromatic

Corresponding Author: Mohamad Azri Sukiran, Malaysian Palm Oil Board, No. 6, Persiaran Institusi,

Bandar Baru Bangi, 43000 Kajang, Selangor, Malaysia 
Hydrocarbon (PAHs) during biomass pyrolysis, particularly at low temperature (Sharma et al., 2004).

The properties of the bio-char obtained after biomass pyrolysis have a direct influence on subsequent bio-char oxidation step, since the amount and type of pores determine the gas accessibility to the active surface sites. Properties of bio-char are decisively affected, not only by properties of parent material, but also by operating conditions used, mainly the heating rate, the maximum temperature experienced and the residence time at this temperature. This is due to the fact that these variables, together with biomass properties, influence the amount and nature of volatiles produced during pyrolysis, as well as their rate of release. These factors also determine both the macroscopicmorphology and themicroscopic porosity of the resultant bio-char (Onay, 2007).

Demirbas (2004) investigated the effect of temperature, particle size, lignin and inorganic matter contents on bio-char yields and reactivity via pyrolysis of agricultural such as olive husk, corncob and tea waste. Sharma et al. (2004) characterized of bio-char from pyrolysis of tobacco using cross-polarization ${ }^{13} \mathrm{C}$ nuclear magnetic resonance (CPMAS NMR), FTIR, scanning electron microscopy (SEM), the BrunauerEmmett-Teller (BET) surface area and the elemental composition.

Guo and Lua (1998) pyrolysed oil palm stones in a stainless-steel vertical reactor to studied the influences of pyrolysis temperature and retention time on the properties of the bio-char. The optimum condition for pyrolysis was found to be at a pyrolysis temperature of $800^{\circ} \mathrm{C}$ for retention time of 3 hours. Maiti et al. (2006) pyrolysed rice husk in a fixed bed rector to determine the characterictics of the bio-char formed for its applicability as a solid fuel.

The solid bio-char can be used as a fuel in form of briquettes or as a char-oil, char-water slurry. Alternatively the bio-char can be upgraded to activated carbon and used in purification processes (Islam et al., 2005). Bio-char is beneficial to farmers as it has the potential to increase conventional agricultural productivity by directly applying carbon into soil. The conversion of biomass to long-lived soil carbon species results in a long-term carbon sink, as the biomass removes atmospheric carbon dioxide through photosynthesis. Bio-char carbon species vary in complexity from graphite-like carbon to high molecular weight aromatic rings, which are known to persist in soil for thousands to millions of years (McHenry, 2009).

In this study, EFB was paralyzed in a fluidized fixed bed reactor under different pyrolysis temperature and the bio-char product obtained were characterized.

\section{MATERIALS AND METHODS}

Sample preparation: EFB was dried at $103^{\circ} \mathrm{C}$, then sieved and separated in fractions of different particle sizes using the test sieve shaker.

Pyrolysis experiments: The pyrolysis of EFB was carried out using a fluidized-fixed bed reactor. An electric furnace heated the reactor with a length of 135 $\mathrm{mm}$ and an inner diameter of $40 \mathrm{~mm}$. The temperature of the reactor was determined by inserting a thermocouple as near the upper fritz as possible. The whole experimental rig that consists of the volatiles and gas collection system is as illustrated in Fig. 1.

The sand bed was fluidized using argon at a rate of 1.5 Litre Per Minute (LPM). The sand bed consisted of $160 \mathrm{~g}$ zircon sand of $180-250 \mu \mathrm{m}$. For every experiment, $2 \mathrm{~g}$ of EFB feedstock was introduced into the bed of zircon sand. The whole experiment must be held for at least a minimum of $20 \mathrm{~min}$ or until no further significant release of gas was observed.

The series of experiments were conducted to determine the effect of the pyrolysis temperatures of $300,400,500,600$ and $700^{\circ} \mathrm{C}$ on bio-char yield. The heating rate was maintained at $30^{\circ} \mathrm{C} \mathrm{min}^{-1}$ and particle size of empty fruit bunches used was 91-106 $\mu \mathrm{m}$.

Before a run, the reactor was weighed. After a run, the cooled reactor was weighted again and the bio-char yield was calculated from the difference. The bio-char remaining in the reactor was elutriated by introducing argon into sand bed.

EFB and bio-char analysis: Characterization of the EFB includes proximate analysis, calorific value and elemental analysis. The proximate analysis was used to determine the moisture content, volatile matter, fixed carbon and ash content in EFB. The calorific value of EFB and bio-char were determined using a bomb calorimeter, Leco AC-350. The carbon, hydrogen and nitrogen contents of EFB and bio-char were determined using a Euro EA3000 series, Elemental Analyzer. Identified by reference to standard calibration and percent element of samples were determined by peak areas. The physical properties of the bio-char relating to specific surface area and total pore volume were obtained by measuring their nitrogen adsorptiondesorption isotherms at $-196^{\circ} \mathrm{C}$ in an Accelerated and Porosimetry System (ASAP 2010, Micromeritics USA). Brunauer-Emmet-Teller (BET) surface area, $\mathrm{S}_{\mathrm{BET}}$ was calculated using the adsorption data in relative pressure ranges from 0.05-0.20. 
Am. J. Applied Sci., 8 (10): 984-988, 2011

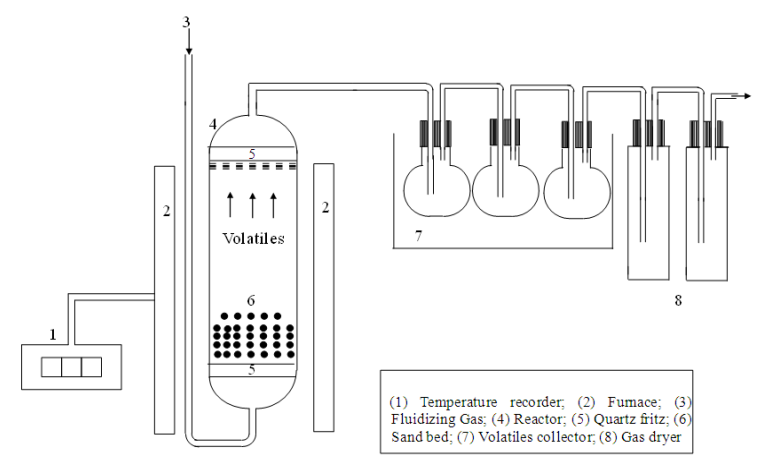

Fig. 1: Schematic diagram of the pyrolysis system

The total pore volume, $\mathrm{V}_{\mathrm{T}}$ was assessed by converting the amount of nitrogen gas adsorbed (expressed in $\mathrm{cm}^{3} \mathrm{~g}^{-1}$ at STP) at relative pressure 0.97 to the volume of liquid adsorbate. The analytical method consists of three steps including dehydration of samples, degassing of sample under low vacuum pressure and nitrogen gas adsorption at $196^{\circ} \mathrm{C}$.

\section{RESULTS}

Raw material: EFB is a by-product of a palm oil mill. The results of proximate analysis, elemental analysis and calorific value of EFB are listed in Table 1. The typical calorific value of EFB of $17.08 \mathrm{MJ} \mathrm{kg}^{-1}$ is generally higher than the energy content of chestnut shell of $15.49 \mathrm{MJ} \mathrm{kg}^{-1}$. The volatiles, fixed carbon and ash content of EFB are 81.9, 12.6 and $3.1 \mathrm{wt} \%$ respectively. The elemental analysis provides the chemical composition of the EFB in elemental forms. EFB contains $53.78 \mathrm{wt} \%$ of carbon, $4.37 \mathrm{wt} \%$ of hydrogen, $47.95 \mathrm{wt} \%$ of oxygen and $0.35 \mathrm{wt} \%$ of nitrogen. The Hydrogen/Carbon (H/C) and Oxygen/Hydrogen $(\mathrm{O} / \mathrm{C})$ ratios of EFB are 0.98 and 0.67 respectively, which reflect a hydrocarbon combustible property. The molecular formula of EFB based on one $\mathrm{C}$ atom can be written as $\mathrm{CH}_{2.27} \mathrm{O}_{0.83} \mathrm{~N}_{0.02}$, taking into consideration only the main elements $(\mathrm{C}, \mathrm{H}$, $\mathrm{O}, \mathrm{N})$ presence in $\mathrm{EFB}$.

Effect of temperature: The effect of final pyrolysis temperature on bio-char yield is shown in Fig. 2. The bio-char yield significantly decreased as the final pyrolysis temperature was raised from $300-700^{\circ} \mathrm{C}$. The highest bio-char yield was $42 \%$ obtained at the temperature of $300^{\circ} \mathrm{C}$ and the lowest bio-char yield was $23 \%$ obtained at the temperature of $700^{\circ} \mathrm{C}$.

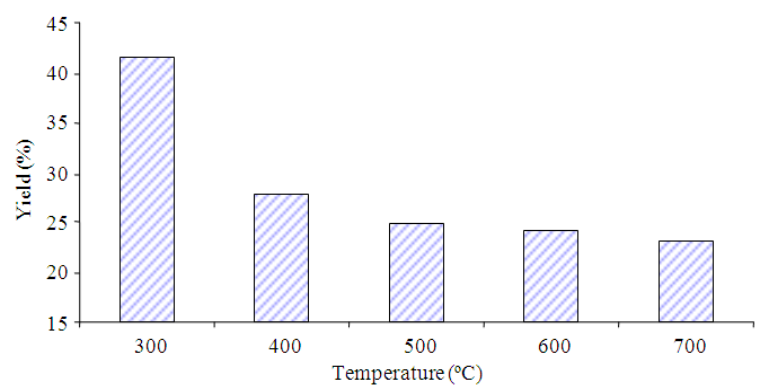

Fig. 2: Yield of bio-char according to different temperatures with a heating rate of $30^{\circ} \mathrm{C} \mathrm{min}{ }^{-1}$ and particle size of 91-106 $\mu \mathrm{m}$

Table 1: Main characteristics of the oil palm Empty Fruit Bunches (EFB)

\begin{tabular}{ll}
\hline Characteristics & EFB \\
\hline Proximate analysis (wt\%) & \\
Volatiles & 81.9 \\
Fixed Carbon & 12.6 \\
Ash & 3.1 \\
Moisture & 2.4 \\
Ultimate analysis (wt $\%)$ & \\
Carbon & 53.78 \\
Hydrogen & 4.37 \\
Nitrogen & 0.35 \\
Oxygen & \\
$\mathrm{H} / \mathrm{C}$ & 41.50 \\
O/C & 0.98 \\
Empirical formula & 0.58 \\
Calorific value $\left(\mathrm{MJ} \mathrm{kg}^{-1}\right)$ & $\mathrm{CH}_{0.98} \mathrm{O}_{0.58} \mathrm{~N}_{0.01}$ \\
\hline a. By difference & 17.08 \\
\hline
\end{tabular}

${ }^{\mathrm{a}}$ : By difference

Table 2: Properties of bio-char product at different temperature with heating rate of $30 \mathrm{C} \mathrm{min}^{-1}$ and particle size of $91-106 \mu \mathrm{m}$

\begin{tabular}{llllll}
\hline & \multicolumn{3}{l}{ Temperature $\left({ }^{\circ} \mathrm{C}\right)$} & & \\
& - & & & \\
Properties & 300 & 400 & 500 & 600 & 700 \\
\hline 1. Calorific Value $(\mathrm{MJ} / \mathrm{kg})$ & 23.23 & 25.98 & 22.94 & 22.98 & 22.98 \\
2. Ultimate analysis wt. \% & & & & & \\
Carbon & 59.62 & 65.94 & 65.32 & 67.87 & 68.63 \\
Hydrogen & 4.02 & 4.42 & 4.56 & 4.04 & 2.71 \\
Oxygen & 34.05 & 25.73 & 28.69 & 25.27 & 27.45 \\
Nitrogen & 2.31 & 3.91 & 1.43 & 2.82 & 1.21 \\
$\mathrm{H} / \mathrm{C}$ molar ratio & 0.81 & 0.80 & 0.84 & 0.71 & 0.47 \\
O/C molar ratio & 0.43 & 0.29 & 0.33 & 0.28 & 0.30 \\
Empirical & $\mathrm{CH}$ & $\mathrm{CH}_{0.80}$ & $\mathrm{CH}_{0.84}$ & $\mathrm{CH}_{0.71}$ & $\mathrm{CH}_{0.47}$ \\
formula & $\mathrm{O}_{0.43}$ & $\mathrm{O}_{0.29}$ & $\mathrm{O}_{0.33}$ & $\mathrm{O}_{0.28}$ & $\mathrm{O}_{0.30}$ \\
& $\mathrm{~N}_{0.03}$ & $\mathrm{~N}_{0.05}$ & $\mathrm{~N}_{0.02}$ & $\mathrm{~N}_{0.04}$ & $\mathrm{~N}_{0.02}$ \\
3. Surface Area $\left(\mathrm{m}^{2} \mathrm{~g}^{-1}\right)$ & 4.54 & 5.76 & 4.85 & 3.95 & 3.34 \\
4. Total pore volume $\left(\mathrm{cm}^{3} \mathrm{~g}^{-1}\right)$ & 0.02 & 0.02 & 0.01 & 0.01 & 0.01 \\
\hline
\end{tabular}

Bio-char characterization: The properties of the biochar according to different temperature were determined and the results obtained are given in Table 2. The calorific values of bio-char according to different temperature are changing between 23 and $26 \mathrm{MJ} \mathrm{kg}^{-1}$. The highest calorific value of bio-char obtained is 25.98 $\mathrm{MJ} \mathrm{kg}^{-1}$ at pyrolysis temperature of $400^{\circ} \mathrm{C}$. 
Am. J. Applied Sci., 8 (10): 984-988, 2011

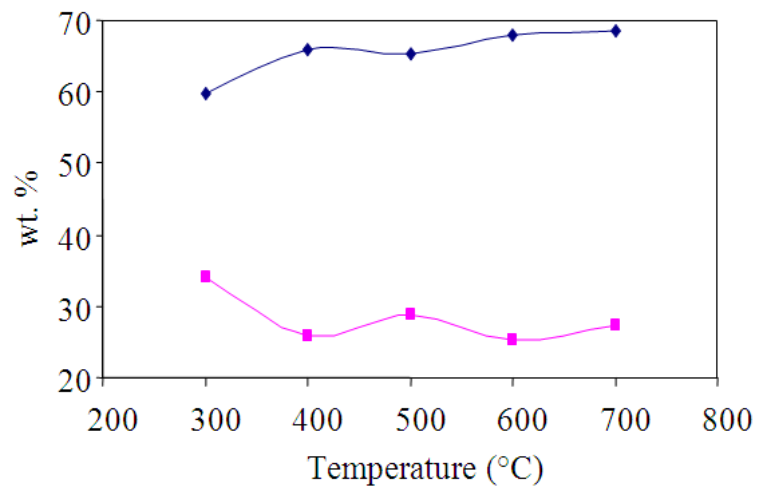

Fig. 3: Effect of temperature on oxygen and carbon content of bio-char

The surface area of bio-char according to different temperature varied between 3.3 and $5.8 \mathrm{~m}^{2} \mathrm{~g}^{-1}$ depending on the production conditions. The maximum surface area of the bio-char occurred at $400^{\circ} \mathrm{C}\left(5.76 \mathrm{~m}^{2}\right.$ $\mathrm{g}^{-1}$ ) and appeared to be associated with the completion of the solidification stage within the bio-char. The total pore volume ranged between 0.01 and $0.02 \mathrm{~cm}^{3} \mathrm{~g}^{-1}$.

The analysis for the elemental compositions of $\mathrm{H} / \mathrm{C}$ molar ratio, $\mathrm{O} / \mathrm{C}$ molar ratio and empirical formula of the bio-char are listed in Table 2. The $\mathrm{H} / \mathrm{C}$ ratios of biochar changed between 0.47 and 0.84 . The highest $\mathrm{H} / \mathrm{C}$ ratio of bio-char obtained was 0.84 at pyrolysis temperatures of $500^{\circ} \mathrm{C}$. The $\mathrm{O} / \mathrm{C}$ ratios of bio-char changed between 0.28 and 0.43 . The highest $\mathrm{O} / \mathrm{C}$ ratio of bio-char obtained was 0.43 at pyrolysis temperature of $300^{\circ} \mathrm{C}$. The percentage of hydrogen and nitrogen ranged from 3-5 to $1-4 \%$ respectively. The highest hydrogen and nitrogen content obtained was 4.56 and $3.91 \%$ at final pyrolysis temperature of $500^{\circ} \mathrm{C}$ and $400^{\circ} \mathrm{C}$ respectively. The molecular formula of the biochar based on one carbon atom is listed in Table 2.

As shown in Fig. 3, the percentage of carbon was ranged from $60-69 \%$ with the highest percentage of carbon obtained was $69 \%$ at pyrolysis temperature of $700^{\circ} \mathrm{C}$. The percentage of oxygen was ranged from $25-$ $34 \%$ with the highest percentage of oxygen obtained was $34 \%$ at pyrolysis temperature of $300^{\circ} \mathrm{C}$. The study of the effect of temperature on carbon and oxygen content had shown that a $600^{\circ} \mathrm{C}$ was the best temperature to produce bio-char with high carbon content and low oxygen content.

\section{DISCUSSION}

Generally, the pyrolysis of the solid biomass conversion increased from a lower temperature to higher temperature (Onay et al., 2001; Sharma et al.,
2004; Sukiran et al., 2009; Tsai et al., 2006). The decrease in bio-char yield with an increase in temperature could either be due to the greater primary decomposition of EFB at higher temperatures or through secondary decomposition of the bio-char residues. The secondary decompositions of the bio-char at higher temperatures may also give rise to other noncondensable gas products (Horne and Williams, 1996).

There is no significant effect of temperature on calorific value of bio-char. Calorific value is a major quality index for fuels. Calorific value obtained defines the energy content of a fuel. The estimation of calorific value from elemental composition of the fuel is one of the basic steps in the performance modeling and calculations of thermal systems (Maiti et al., 2006).

Surface area is important in chemical kinetics. Increasing the surface area of a substance generally increases the rate of a chemical reaction. The ensuing carbonization step at high temperature was detrimental to the development of a porous structure in the bio-char (Guo and Lua, 1998). As it is know, the high carbon content and low oxygen content of bio-char make it suitable to act as solid fuel.

\section{CONCLUSION}

In this study, pyrolysis of oil palm empty fruit bunches was carried out using a fluidized fixed bed reactor. The highest bio char yield of $41.56 \%$ was obtained at an optimum pyrolysis temperature of $300^{\circ} \mathrm{C}$ with particle size of 91-106 $\mu \mathrm{m}$ and the heating rate of $30^{\circ} \mathrm{C} \mathrm{min}^{-1}$. The highest calorific value of the bio-char obtained was $25.98 \mathrm{MJ} \mathrm{kg}^{-1}$.

\section{ACKNOWLEDGEMENT}

The researchers wish to thank the Director-General of the Malaysian Palm Oil Board (MPOB) for permission to publish this study. We would like to acknowledge all staff of the Energy and Environment Unit, MPOB, for their valuable assistance throughout the implementation of the projects.

\section{REFERENCES}

Demirbas, A., 2004. Effects of temperature and particle size on bio-char yield from pyrolysis of agricultural residues. J. Anal. Applied Pyrol., 72: 234-248. DOI: 10.1016/j.jaap.2004.07.003

Guo, J. and A.C. Lua, 1998. Characterization of chars pyrolyzed from oil palm stones for the preparation of activated carbons. J. Anal. Applied Pyrol., 46: 113-125. DOI: 10.1016/S0165-2370(98)00074-6 
Horne, P.A. and P.T. Williams, 1996. Influence of temperature on the products from the flash pyrolysis of biomass. J. Fuel, 75: 1051-1059. DOI: 10.1016/0016-2361(96)00081-6

Islam, M.N., M.R. Alam Beg and M.R. Islam, 2005. Pyrolytic oil from fixed bed pyrolysis of municipal solid waste and its characterization. J. Renew. Energy, 30: 413-420. DOI: 10.1016/j.renene.2004.05.002

Maiti, S., S. Dey, S. Purakayastha and B. Ghosh, 2006. Physical and thermochemical characterization of rice husk char as a potential biomass energy source. J. Biores. Technol., 97: 2065-2070. DOI: 10.1016/j.biortech.2005.10.005

McHenry, M.P., 2009. Agricultural bio-char production, renewable energy generation and farm carbon sequestration in Western Australia: Certainty, uncertainty and risk. J. Agric. Ecosys. Environ., 129 : $1-7 . \quad$ DOI: 10.1016/j.agee.2008.08.006

Onay, O., 2007. Influence of pyrolysis temperature and heating rate on the production of bio-oil and char from safflower seed by pyrolysis, using a wellswept fixed-bed reactor. J. Fuel Proc., 88: 523-531. DOI: 10.1016/j.fuproc.2007.01.001
Onay, O., S.H. Beis and O.M. Kockar, 2001. Fast pyrolysis of rape seed in a well-swept fixed-bed reactor. J. Anal. Applied Pyrol., 58: 995-1007. DOI: 10.1016/S0165-2370(00)00133-9

Sensoz, S., I. Demiral and H.F. Gercel, 2006. Olive bagasse (Olea europea L.) pyrolysis. J. Biores. Technol., 97: 429-436. DOI: 10.1016/J.BIORTECH.2005.03.007

Sharma, R.K., J.B. Wooten, V.L. Baliga, X. Lin and W.G. Chan et al., 2004. Characterization of chars from pyrolysis of lignin. J. Fuel, 83: 1469-1482. DOI: 10.1016/j.fuel.2003.11.015

Sukiran, M.A., M.C. Chow and N.K. Abu Bakar, 2009. Bio-oils from pyrolysis of oil palm empty fruit bunches. Am. J. Applied Sci., 6: 869-875. DOI: 10.3844/ajassp.2009.869.875

Tsai, W.T., M.K. Lee and Y.M. Chang, 2006. Fast pyrolysis of rice straw, sugarcane bagasse and coconut shell in an induction-heating reactor. J. Anal. Applied Pyrol., 76: 230-237. DOI: 10.1016/j.jaap.2005.11.007 